\title{
CORRECTION
}

View Article Online

View Journal I View Issue

\section{Correction: Paper-based molecular diagnostic for Chlamydia trachomatis}

Cite this: RSC Adv., 2015, 5, 62585

Jacqueline C. Linnes, ${ }^{a}$ Andy Fan, ${ }^{a}$ Natalia M. Rodriguez, ${ }^{a}$ Bertrand Lemieux, ${ }^{b}$

Huimin Kong ${ }^{\mathrm{b}}$ and Catherine M. Klapperich ${ }^{\star a}$

DOI: $10.1039 / \mathrm{c} 5 \mathrm{ra} 90070 \mathrm{k}$

www.rsc.org/advances

Correction for 'Paper-based molecular diagnostic for Chlamydia trachomatis' by Jacqueline C. Linnes et al., RSC Adv., 2014, 4, 42245-42251.

The authors apologise for the errors in the caption of Fig. 1 in the original manuscript. The correct figure and caption are as follows:

A

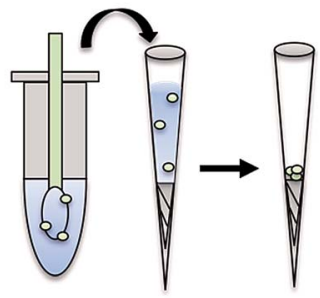

B

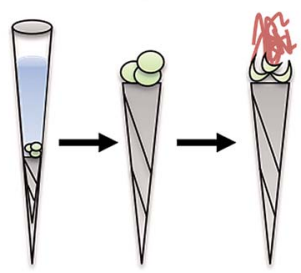

$\mathbf{C}$

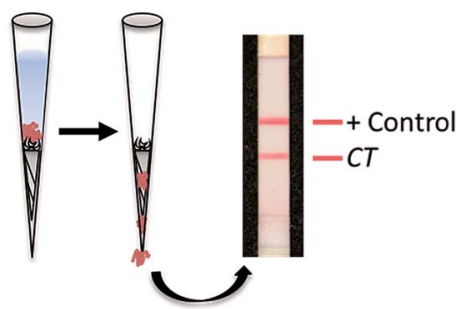

Fig. 1 Schematic of the method to perform the paper-based cell lysis, amplification, and detection. (A) Sample is added to the pipette tip and cells are filtered onto the paper support. (B) tHDA mastermix is added to the pipette tip and the tip is incubated at $65^{\circ} \mathrm{C}$ to lyse cells and amplify DNA. (C) Elution buffer is added to the pipette tip and the amplified DNA is eluted onto the lateral flow test.

The Royal Society of Chemistry apologises for these errors and any consequent inconvenience to authors and readers. 